\title{
GENETIC AND PHYNOTYPIC CORRELATIONS OF AGE AT FIRST CALVING WITH SOME CALF-HOOD FITNESS AND HEALTH TRAITS IN HOLSTEIN HEIFERS
}

\author{
M.S. Mousa ${ }^{1}$, A. J. Seykora ${ }^{2}$, M. A. Abdellatif ${ }^{3}$ and E. F. Mousa ${ }^{1,4}$ \\ 1- Department of Animal Production, Assiut University, Assiut, Egypt, 2- Department of Animal Science, \\ University of Minnesota, Saint Paul, USA, 55108, and 3- Department of Poultry Production, Assiut \\ University, Assiut, Egypt, 4- Department of Animal Production and breeding, Qassim University, Qassim, \\ Kingdom of Saudi Arabia
}

\section{SUMMARY}

Objectives of this study were to estimate the effects of calf-hood fitness and health traits on age at first calving (AFC). Data of 2230 US Holstein heifers were collected from three farms located in Minnesota from 2003 to 2011 were used. AFC, calculated as a difference between birth date and date of first calving ranged from 571 to 1059 days $(\bar{x}=716.66 \pm 47.4)$. Multiple trait animal models were applied using REMLf90 software. Fixed effects considered as revealed in; a previous nutritional experiment applied on almost half of these animals $(n=1226),(P<0.01)$, and interaction between month and year of birth, while covariate effects were serum protein upon arriving to facility $(S P),(P<0.01)$. Fitness traits effects included arrival to facility body weight (ABW), weaning weight (W56), weaning hip height (HH56), adjusted weight to 200d (W200), and adjusted hip height to $200 d$ (HH200). Health traits recorded were scours $(S c)$ and respiratory disease $(R D)$. Health traits were recorded as categorical traits according to incidence of occurrence ( $0:$ non occurrence; 1 : occurrence once; and 2: occurrence twice or more). Heritability estimate of AFC was (0.07). Genetic correlations between calf-hood fitness traits and $A F C$ were highly significant $(0.45,0.38,0.34,0.75$, and 0.33 ) with ABW, W56, HH56, W200, and HH200, respectively. Meanwhile, genetic correlations between AFC and both health traits (Sc and RD) were (-0.19 and-0.01), respectively. Therefore, it is possible to build a selection index comprising calf-hood's fitness and health performance and AFC.

Keywords: age at first calving, fitness traits, health traits, heritability, genetic correlation

\section{INTRODUCTION}

Age at first calving is defined as the number of days from birth to day of first calving. At this stage, replacement heifers are not generating any income. Instead, this rearing period requires considerable capital expenditures including feed, housing, and veterinary expenses that had been estimated by Heinrichs (1993) as 15 to $20 \%$ of the total expenses related to milk production. Cooke et al. (2012) showed that rearing replacement heifers is considered a costly process where early AFC can reduce this cost.
Tozer and Heinrichs (2001) showed that reducing AFC from 25 to 24 or 21 months decreased replacement costs by $4.3 \%$ or $18 \%$, respectively. Meanwhile, increasing AFC to 29 months led to increase cost by $14 \%$, also led to keep more replacement heifers in herds to maintain herd size. Meanwhile, Hoffman et al. (1992), reported that acceptable milk yield and levels of dystocia could be achieved in modern Holstein heifers when calving at ages $<22$ mo due to genetic selection and advances in nutritional management.

Previous studies on heritability estimates of AFC in different breeds are shown in Table (1).

Table 1. Estimates of heritability for AFC in different breeds

\begin{tabular}{llll}
\hline Breed & Estimate & Statistical models & References \\
\hline Boran cattle in Kenya & $0.04 \pm 0.06$ & Univariate animal models & Wasike et al. $(2009)$ \\
Iranian Holstein & $0.014 \pm 0.005$ & $\mathrm{NA}^{*}$ & Chookani et al. $(2010)$ \\
Angus Orejinegro Zebu & $0.15 \pm 0.13$ & Multiple trait mixed model & Vergara et al. $(2009)$ \\
Romosinuano & $0.16 \pm 0.09$ & Means of linear models & Suárez et al. $(2006)$ \\
South African cattle & $0.26 \pm 0.02$ & Multiple trait animal model & Makgahlela et al. (2008) \\
Iranian Holstein & 0.086 & Animal model & Nilforooshan and Edriss (2004) \\
Iranian Holstein & $0.19 \pm 0.005$ & Single and two trait animal model & Arough et al. (2011) \\
\hline
\end{tabular}

*: NA: Not available.

Ettema and Santos (2004) evaluated the effects of altering age at breeding to affect a change in AFC by using Holstein heifers, their results showed that medium and high AFC increase rearing cost than low
AFC by $40.34 \$$ and $107.89 \$$ for each heifer, respectively.

In the past, growth has always been defined as weight gain per day. Other body size criteria such as 
wither height, body condition score, body length, and pelvic area are now available to aid growth definitions. These measurements should be used because they are related to lactation performance and animal health than body weight. Hoffman et al. (1997) used three ranges (lower, average, and upper) for weight, wither height, body length, pelvic area, and body condition score (BCS) as a criteria for a recommended optimum body size of Holstein replacement heifers at first calving.

One of the aims of this study was to estimate genetic correlations between health traits and AFC. Unfortunately, there is no direct selection for health traits in calves due to: 1) difficult and expensive health data recording; 2) needs a large population to fellow up and diagnosis; 3) health traits have low heritability, Heringstad (2010). Because of the above reasons, health traits have been the last to be incorporated into genetic evaluation programs for dairy calves. Steine et al. (2008) reported that only in Nordic countries, direct selection for improved disease resistance had been carried out for more than 30 years.

In 2007, a national dairy cattle health and disease data management system was initiated in Canada. The main objective was to provide dairy producers and veterinarians with information on herd management and to establish a national genetic evaluation system for genetic selection for disease resistance, Koeck et al. (2012). Calving survival traits had gained attention recently especially for beef breeders. These traits are assumed to have underlying continuous genetic and environmental influences, but the problem is the low heritability estimates of these traits, Guerra et al. (2006).USDA (2007) performed a comprehensive study to document calf losses in North America and found that $15.9 \%$ of calves die before weaning, $8.1 \%$ of this percentage resulted from events that occur during calving. These losses are classified as stillbirths. The remaining deaths $(7.8 \%)$ were associated with health problems caused by pathogens acquired after birth, most commonly manifested as diarrhea and respiratory problems leading to calf death. Heringstad et al. (2008) reported that there could be a possible association between calf diseases and other economic traits recorded later in cow's life, such as growth, fertility, and production, therefore from a breeding perspective, data on calf-hood diseases may be valuable.

Morrison et al. (2013) reported that calves born with no immunity, therefore feeding colostrum is important since its value in disease management has long been known. They also reported that calves with poor colostrum intake and inadequate immunity in early life were found to cause a $40 \%$ increase in treatment costs on farm. Most common parameter used under field conditions to measure positive or failure of passive transfer of immunoglobulins (Ig) is serum total protein (SP) since it is highly correlated with immunoglobulins especially IgG levels.
The aim of the present study is to focus on calfhood fitness and health traits on their effects on AFC and to investigate if it is possible to build selection indices to select calves with a reduction in AFC. Unfortunately, studies taking calf-hood traits and following dairy calves through calving, their first lactation, and their complete lifetime production are few.

\section{MATERIALS AND METHODS}

Age at first calving was calculated as the difference between birth date and date of first calving in days and was available on 2230 Holstein heifer calves collected from three commercial dairy farms picked up twice weekly at two to four days of age and remained at the University of Minnesota, Southern Research and Outreach Center (SROC) Calf and Heifer Research and Extension facility in Waseca, Minnesota up to six to seven months of age.

During winter months, calf blankets are used at pick-up and remain on the calves at the discretion of (SROC) staff until they adjust to their new environment. In the nursery phase, calves are housed in one of two $60 \mathrm{~m} \times 9 \mathrm{~m}$ curtain side-wall naturally ventilated calf barns. Each barn contains two $27 \mathrm{~m} \mathrm{x}$ $9 \mathrm{~m}$ rooms with 40 individual pens (approx nine sqm /calf) within each room. A six $\mathrm{m} x$ nine $\mathrm{m}$ mixing and feed storage area is centrally located in each barn. The rooms are managed as an all-in, all out system. All pen panels are removed and power washed between calf groups. All bedding material is removed and the remaining front gates and rear panel holders are also power washed. In winter, chopped straw is used for bedding calf pens while sawdust is used in summer months.

Upon arrival, calves are weighed, and two jugular blood samples drawn. One sample is used to check total serum proteins using a refractometer (scale of serum protein). A second sample for whole blood analyses by an outside laboratory to identify persistently infected of Bovine virus diarrhea (BVD) calves.

Nearly half of calves $(n=1226)$ used in this study were involved in a nutritional experiment, therefore this trait was added as a fixed effect in the model in order to eliminate this effect on studied traits.

Analyses of variance using GLM procedures (SAS, 2004) were conducted to test the fixed effects of farm, year of birth, month of birth, season of birth, a previous nutritional experiment applied on nearly half of these animals $(n=1226)$, the interactions between month of birth and year of birth, year and season, and year and farm, revealed no significant effect $(P>0.10)$ of year of birth, month of birth, season of birth and interactions between year $\mathrm{X}$ season, and year X farm, therefore they were deleted from the final model in order to calculate the least squares means for each level of each factor.

Animal mixed models were applied by using REMLf90 software package, Misztal et al. (2002) to estimate heritability of AFC, phenotypic, genetic and 
residual correlations between calf-hood traits and AFC. The following model was applied to fit the data:

$\mathrm{Y}_{\mathrm{ijklmn}}=\mathrm{h}_{\mathrm{i}}+\mathrm{mp}_{\mathrm{jk}}+\mathrm{t}_{\mathrm{l}}+\mathrm{s}_{\mathrm{m}}+\mathrm{a}_{\mathrm{n}}+\mathrm{e}_{\mathrm{ijklmno}}$,

where:

$\mathrm{Y}_{\mathrm{ijklmno}}=$ observation of studied traits;

$h_{i} \quad=$ fixed effect of $i^{\text {th }}$ herd $i=(1 \ldots . .3)$;

$\mathrm{mp}_{\mathrm{jk}} \quad=$ interaction between $\mathrm{j}^{\text {th }}$ month of birth and $\mathrm{k}^{\text {th }}$ year of birth;

$\mathrm{t}_{1} \quad=$ fixed effect of treatments within nutritional trails ${ }^{1}$;

$\mathrm{s}_{\mathrm{m}} \quad=$ covariate effect of serum protein;

$\mathrm{a}_{\mathrm{n}} \quad=$ random animal effect;

$\mathrm{e}_{\mathrm{ijklmno}}=$ random residual effect associated with the observation ijklmno.

1: this effect was excluded when estimating $\mathrm{ABW}$.

In matrix notation form, the multiple trait models can be described as:

$\mathrm{Y}=\mathrm{Xb}+\mathrm{Zu}+\mathrm{e}$,

where:

$\mathrm{Y}=$ vector of observations of studied traits;

$\mathrm{X}=$ incidence matrix relating the observations to the fixed effects;

$\mathrm{b}$ = vector of fixed effects;

$\mathrm{Z}$ = incidence matrix relating the observations to the random effects;

$\mathrm{u}=$ vector of random effects;

e = vector of residual effects;

The expectations and assumed variances are $\mathrm{E}(\mathrm{y})$ $=\mathrm{Xb} ; \mathrm{E}(\mathrm{u})=\mathrm{E}(\mathrm{e})=0 ; \mathrm{V}(\mathrm{u})=\mathrm{G} ; \mathrm{V}(\mathrm{e})=\mathrm{R} ; \operatorname{cov}(\mathrm{u}, \mathrm{e})$

$=0 ;$ and $\mathrm{V}(\mathrm{Y})=\mathrm{ZGZ}+\mathrm{R}$.
The convergence criteria used in this analysis was the variance of simplex values (-2 log likelihood) of $<10^{-6}$ and the value of ( $-2 \log$ likelihood) did not change from the previous solution by at least two decimal points. To ensure global convergence, programs were restarted with previous solutions at local convergence until convergence occurred at the same maximum. Overall, number of iterations required to reach convergence could be affected by the number of animals, number of random effects in the model and number of traits studied, (El-Arian et al., 2003).

The animal pedigree file was generated by tracing the pedigrees of cows with data 11 generations back and contained the relationship of 26.553 animals.

\section{RESULTS AND DISCUSSION}

Mean, standard deviation (SD), and range of fitness traits included calf weight once arrived to SROC facility (ABW) since these animals were picked twice weekly from origin farms, weaning weight (W56) at 56d, weaning hip height (HH56), adjusted weight to 200d (W200), and adjusted hip height to 200d (HH200) with the reproductive trait: age at first calving (AFC) are shown in Table (2).

Percentage of incidence of occurrence of diseases scours and respiratory disease are recorded in Table (3).

Table 2. Structure and descriptive statistics for studied traits

\begin{tabular}{lcccc}
\hline Observations $^{\text {a }}$ & Mean & SD & Min. & Max. \\
\hline SP $(\mathrm{g} / \mathrm{dl})$ & 5.4 & 0.77 & 2.6 & 9 \\
ABW $(\mathrm{Kg})$ & 39.4 & 5.0 & 20.86 & 58.96 \\
W56 $(\mathrm{Kg})$ & 73.8 & 9.2 & 43.9 & 104.8 \\
W200 $(\mathrm{Kg})$ & 206.6 & 21.2 & 68.04 & 288 \\
HH56 $(\mathrm{cm})$ & 89.6 & 3.3 & 74.93 & 98.4 \\
HH200 $(\mathrm{cm})$ & 114.4 & 3.6 & 100.33 & 127 \\
AFC $(\mathrm{d})$ & 716.7 & 47.4 & 571 & 1059 \\
\hline
\end{tabular}

a:SP: Serum Protein; ABW: Arrival body weight; W56: Weight at 56d; W200:Weight after standardized to 200d; HH56: Hip Height at 56d; HH200: Hip Height standardized to 200d; Sc: scours; RD: respiratory disease; AFC: age at first calving.

Table 3. Incidence of occurrence for health traits

\begin{tabular}{|c|c|c|c|}
\hline Health traits $^{\mathrm{a}}$ & Incidence occurrence (\%) & & \\
\hline & $\mathbf{0}$ & 1 & 2 \\
\hline Sc & 48.83 & 49.87 & 1.30 \\
\hline RD & 92.6 & 6.91 & 0.13 \\
\hline
\end{tabular}

a:Sc: scours; RD: respiratory disease

As shown in Table (2), mean of SP was 5.4 with a range of 2.6 to $9 \mathrm{~g} / \mathrm{dl}$, Chester-Jones and Broadwater (2009) showed that if calves have received enough high quality colostrum, serum total protein will be 5.5 grams per deciliter $(\mathrm{g} / \mathrm{dl})$ or greater, if the value falls between 5.0 and $5.5 \mathrm{~g} / \mathrm{dl}$, there is a marginal risk for mortality and morbidity, if the value is less than $5.0 \mathrm{~g} / \mathrm{dl}$ the calf will be at high risk for health problems. Villarroel et al. (2013) reported that maximum concentration of SP is when calves reach 2 - 3 days of age. After that, concentrations decreased by approx. $0.07 \mathrm{~g} / \mathrm{dL}$, this statement indicates that these estimates were at the maximum concentration of SP since these estimates were taken at the same age (2-3days).

Mean of W56, and W200 were 73.8, and 206.6 $\mathrm{kg}$, respectively. Heinrichs and Hargrove (1986) working on 5723 Holstein heifers collected from 163 herds found the mean weight of 2 mo and 6 mo as 82.1 , and $168.6 \mathrm{~kg}$, respectively. Meanwhile, mean estimates for HH56, and $\mathrm{HH} 200$ were 89.6, and $114.4 \mathrm{~cm}$ respectively. Results from Heinrichs and 
Hargrove (1986) showed 85.6 and 101.1 for height at two and six months, respectively. Difference in values shown between studied traits and Heinrichs and Hargrove (1986) traits could be due to different days on taking these values in different studies.

Mean age at first calving was 716.7 days (24 month). Makgahlela et al. (2008) showed that the mean AFC in South African Holstein found it as 840 days (28 month), also several authors (Arough et al., 2011 and Chookani et al., 2010) found the mean of AFC for Iranian Holstein as 811.1 days (26.6 month).Mean of AFC according to year are shown in figure (1). It is obvious that the protocol in (SROC) University facility is to low AFC in order to reduce rearing costs due to decreased feed, labor and housing costs.

Incidence of occurrence of Sc for years from 2003 to 2011 combined was $51.17 \%$ (as shown in Table 3). Stoltenow and Vincent, (2003) showed that the first three weeks of the calf life is important because any infection on that age resulted in some level of scours due to the fact that its gut is still so immature during that period and considered the weakest point of the calf's system. The cause could be a single agent such as salmonella. But if a variety of agents are present, the diagnosis of the causal pathogen cannot be accurately made.

Incidence of occurrence for RD (both 1 and 2) was $7.04 \%$, these estimate was lower than Snowder et al. (2005) working on 18,112 records from 9 different beef breeds collected from 1987 - 2001 reported that incidence of RD exceeded $20 \%$ in early years (1987 -1991), while it lowered to $14 \%$ in late years $(1992-2001)$. They showed that the reason for this was; 1) modifying vaccines with higher effective in later years and; 2) changing castration method from surgical to mechanical.

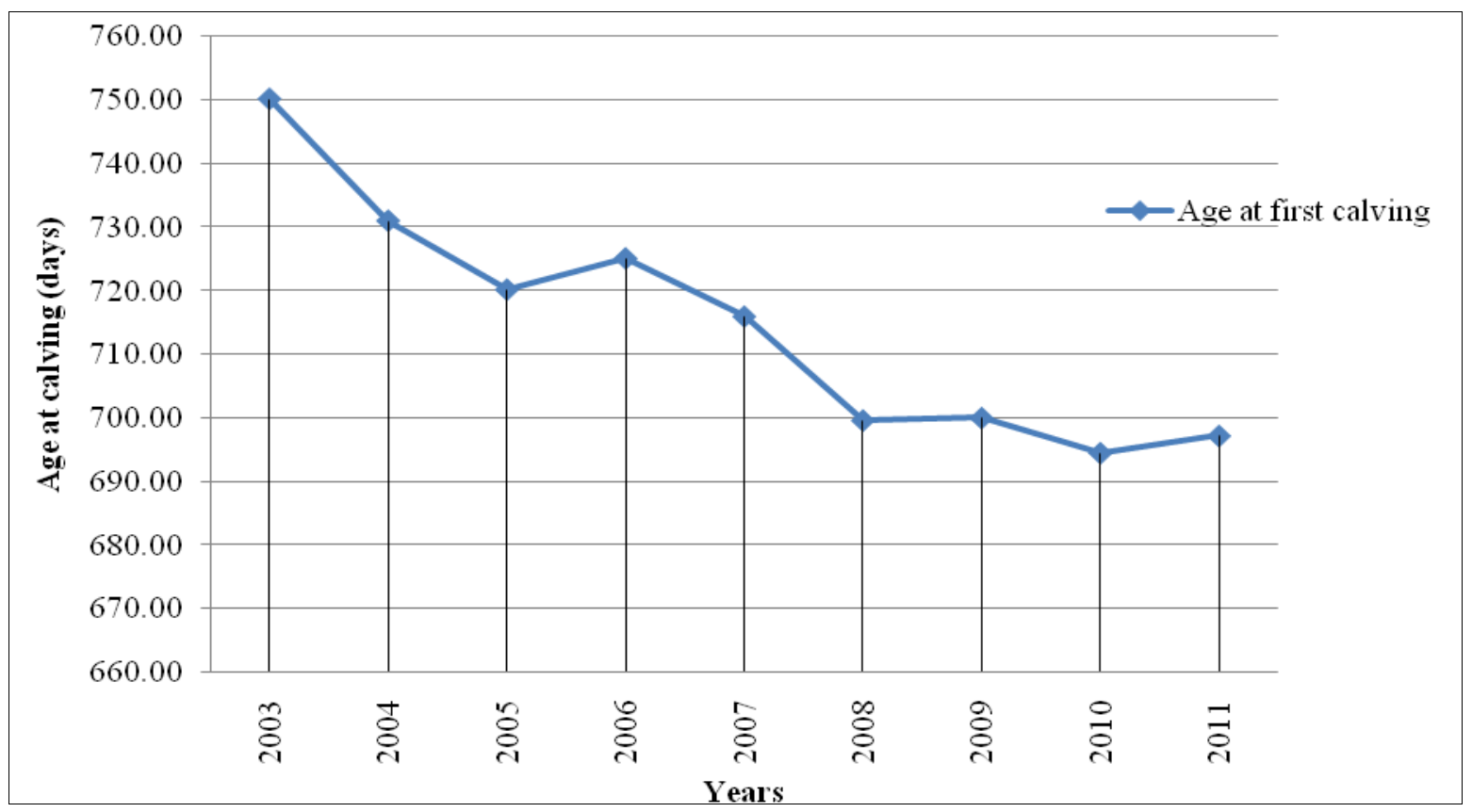

Fig. 1.Mean estimate of age at first calving according to year

Heritability estimate for AFC in this study was (0.07). This estimate was close to Wasike et al., (2009) for Boran cattle in Kenya $(0.04 \pm 0.06)$, Chookani et al. (2010) for Iranian Holstein (0.014 0.005), Nilforooshan and Edris (2004) in Iranian Holstein (0.086). Meanwhile, this estimate was lower than $(0.15 \pm 0.13)$ obtained by Vergara et al. (2009) for Angus Blanco Orejinegro Zebu cattle in Colombia, (0.16 \pm 0.09 ; Suárez et al., 2006) on Romosinuano in Colombia cattle, $(0.19 \pm 0.005$; Arough et al., 2011) on Iranian Holstein. On the other hand, Makgahlela et al. (2008) reported a medium heritability estimate of AFC on South African cattle as $(0.26 \pm 0.02)$.

Arough et al. (2011) reported that there could be several factors for the difference in heritability estimate such as: breed of animal, management system, environmental factors, size and structure of data, model of analyses, and statistical methods employed. Several authors (Kadermideen 2004, Makgahlela et al., 2008) reported that, due to the low heritability for AFC, selection for improving this trait in dairy cattle would not worthwhile.

Considering $\mathrm{AFC}$ as a fertility trait, De Jong (1998) found high additive genetic variation in fertility traits. Accordingly it could be possible to improve these traits genetically through selection, and this could be achieved by increasing the amount of information used in the genetic evaluation (e.g., using offspring information). Incorporation of traditional measures of fertility and all these correlated traits, directly and indirectly, could be used to improve the accuracy of genetic predictions for fertility traits (Makgahlela et al., 2008).

It is stated that the cow become profitable when entering the second lactation, therefore several farmers considers calf-hood stage and the first lactation stage as considerable capital expenditures. 
Lin et al. (1988), and Van Amburgh et al. (1998) reported that milk yield in second and greater lactations has consistently been unaffected by reduced $\mathrm{AFC}$, therefore, it will be beneficial lowering AFC.
Highly significant $(\mathrm{P}<0.01)$ genetic and phenotypic correlations between calf-hood fitness traits and AFC ranged from 0.33 to 0.75 as shown in Table (4). These estimates show a positive genetic relationship therefore, adding these traits in the selection indices will improve AFC genetically.

Table 4.Genetic correlations between calf-hood traits and AFC

\begin{tabular}{llcc}
\hline \multirow{2}{*}{ Calf-hood traits } & \multicolumn{3}{c}{ AFC } \\
\cline { 2 - 4 } & Genetic correlation & Residual correlation & Phenotypic correlation \\
\hline FBW & & & \\
W56 & $0.45^{* *}$ & $-0.07^{*}$ & $0.38^{* *}$ \\
W200 & $0.38^{* *}$ & -0.04 & $0.34^{* *}$ \\
HH56 & $0.75^{* *}$ & $-0.13^{* *}$ & $0.62^{* *}$ \\
HH200 & $0.34^{* *}$ & -0.04 & $0.30^{* *}$ \\
Health traits & $0.33^{* *}$ & -0.05 & $0.28^{* *}$ \\
Sc & & & $-0.19^{* *}$ \\
RD & $-0.19^{* *}$ & 0.00001 & -0.03 \\
\hline
\end{tabular}

a:ABW: Arrival body weight; W56: Weight at 56d; W200:Weight after standardized to 200d; HH56: Hip Height at 56d; HH200: Hip Height standardized to 200d; Sc: scours; RD: respiratory disease. *: significant at 0.05; **: highly significant at 0.01 .

Negative genetic and phenotypic correlations between health traits and AFC as shown in Table (4) indicate that disease occurrence of both scours and respiratory illness at calf-hood stage increase AFC. This result agrees with Heinrichs et al. (2005) who reported that health of calves during the first 4 mo of life and antibiotic treatment for scours or pneumonia increase AFC.

\section{CONCLUSION}

Healthy, productive herd replacements are the result of good management before the calves are conceived and continue to the time when they enter the milking herd. Accurate records must be kept so a sound breeding program can be followed. The total process ensures that genetically superior animals will enter the herd. Once calves are born, they should be provided with a healthy environment including proper facilities, water, high quality feeds, daily observations, and health care. This kind of attention should extend beyond the baby calves. A carefully managed, well-planned facility enables dairy farmers to efficiently use their time and labor while rearing healthy replacements that freshen at 24 months of age.

Due to the low heritability estimate of AFC reported in this study (0.07) it seems that this trait is more controlled by environmental and management practices rather that genetically practices, it will be beneficial to add calf-hood fitness and Sc traits (according to their high significance) to the selection indices to reach the target $\mathrm{AFC}$ according to each farm strategies.

\section{ACKNOWLEDGEMENT}

The authors thank Minnesota USDA for providing data used in this study. We also gratefully acknowledge Ignacy Misztal and Shogo Tsuruta at the University of Georgia (Athens) for use of the REMLF90 computer program. Special thanks to the Egyptian culture and missions affairs for funding this project to collect data and statistical software to perform this analysis in the USA.

\section{REFERENCES}

Arough, H. F., A. A. Aslaminejad, and H. Farhangfar, 2011. Estimation of Genetic Parameters and Trends for Age at First Calving and Calving Interval in Iranian Holstein Cows. Journal of Research in Agricultural Science, 7: 79-87.

Chester-Jones, H., and N. Broadwater, 2009. Colustrum. Minnesota dairy days. http://www.extension.umn.edu/agriculture/dair y/calves-and-heifers.

Chookani, A., M. Dadpasand, H.R. Mirzaei., M. Rokouii and M.B. Sayad Nezhad, 2010. An estimation of genetic parameters for some reproductive traits and their relationships to milk yield in Iranian Holstein cattle. Iranian Journal of Animal Science, 40: 53-61.

Cooke, J. S., Zhangrui Cheng, Nicola E. Bourne, D. Claire Wathes, 2012. Association between growth rates, age at first calving and subsequent fertility, milk production and survival in Holstein-Friesian heifers. Open Journal of Animal Science, 3:1-12.

De Jong, G, 1998. Fertility in the index for daughters Netherlands. Interbull Bull, 18: 102105.

El-Arian, M. N., H. G. El-Awady, and A. S. Khattab, 2003. Genetic analysis for some productive traits of Holstein Friesian cows in Egypt through MTDFREML program. Egyptian Journal Animal Production, 40:99109. 
Ettema, J. F. and J. E. P. Santos, 2004. Impact of age at calving on lactation, reproduction, health, and income in first-parity Holsteins on commercial farms. Journal Dairy Science, 87:2730-2742.

Guerra, J. L. L., D. E. Franke and D. C. Blouin, 2006. Genetic parameters for calving rate and calf survival from linear, threshold, and logistic models in a multibreed beef cattle population. Journal Animal Science, 84: 31973203.

Heinrichs, A. J. and G. L. Hargrove, 1986. Standards of Weight and Height for Holstein Heifers. Journal Dairy Science, 70:653-660.

Heinrichs, A. J., 1993. Raising dairy replacements to meet the needs of the 21 st century. Journal Dairy Science, 76:3179-3187.

Heinrichs, A. J., B. S. Heinrichs, O. Harel, G. W. Rogers and N. T. Place, 2005. A Prospective Study of Calf Factors Affecting Age, Body Size, and Body Condition Score at First Calving of Holstein Dairy Heifers.Journal Dairy Science, 88:2828-2835.

Heringstad, B., Y. M. Chang, D. Gianola and O. Osteras, 2008. Short communication: Genetic analysis of respiratory disease in Norwegian red calves. Journal Dairy Science, 91: 367370.

Heringstad, B., 2010. Genetic analysis of fertilityrelated diseases and disorders in Norwegian Red cows. Journal Dairy Science,93:27512756.

Hoffman, P. C., 1997. Optimum body size of Holstein replacement heifers. JournalAnimal Science, 75:836-845.

Hoffman, P. C. and D. A. Funk, 1992. Applied dynamics of dairy replacement growth and management. Journal Dairy Science,75: 25042516.

Kadermideen, H.N., 2004. Genetic correlations among body condition score, somatic cell score, milk production, fertility and conformation traits in dairy cows. Journal Animal Science, 79:191-201.

Koeck, A., F. Miglior, D. F. Kelton and F. S. Schenkel, 2012. Health recording in Canadian Holsteins: Data and genetic parameters. Journal Dairy Science, 95: 4099-4108.

Lin, C. Y., A. J. McAllister, T. R. Batra, A. J. Lee, G. L. Roy, J. A. Vesely, J. M. Wauthy and K. A. Winter, 1988. Effects of early and late breeding of heifers on multiple lactation performance of dairy cows. Journal Dairy Science, 71:2735-2743.

Makgahlela, M. L., C.B. Banga, D. Norris, K. Dzama and J.W. Ngambi, 2008. Genetic analysis of age at first calving and calving interval in South African Holstein cattle. Asian Journal of Animal and Veterinary Advance, 3:197-205.

Misztal, I., S. Tsuruta, T. Strabel, B .Auvray, T . Druet and D.H Lee, 2002. BLUPF90 and related programs (BGF90). Proceedings of the $7^{\text {th }}$ World Congress on Genetics Appliedto LivestockProduction, Montpellier, France,Communicationno, 28-06.

Morrison, S., G. Scoley and J. Barley, 2013. The impact of calf health on future performance. Veterinary Ireland Journal, 3: 264-268.

Nilforooshan, M. A., and M. A. Edriss, 2004. Effect of Age at First Calving on Some Productive and Longevity Traits in Iranian Holsteins of the Isfahan Province. Journal Dairy Science, 87:2130-2135.

Radcliff, R. P., M. J. Vandehaar, L. T. Chapin, T.E. Pilbeam, D. K. Beede, E. P. Stanisiewski and H. A. Tucker, 2000. Effects of diet and injection of bovine somatotropin on prepubertal growth and firstlactation milk yields of Holstein cows. Journal Dairy Science, 83:23-29.

SAS, 2004. SAS/STAT User's Guide. $9^{\text {th }}$ edition. SAS Institute Inc., Cary, NC.

Snowder, G. D., L. D. Van Vleck, L. V. Cundiff, and G. L. Bennett, 2005. Influence of breed, heterozygosity, and disease incidence on estimates of variance components of respiratory disease in pre-weaned beef calves. Journal Animal Science. 72:1247-1261.

Suárez, M., G. Ossa and J Pérez, 2006. Environmental and genetic aspects that influence on age at first calving in a native cattle of Colombia (Romosinuano). Rev. MVZ Córdoba, 11:738-743.

Steine, G., D. Kristofersson, and A. G. Guttormsen, 2008. Economic evaluation of the breeding goal for Norwegian Red dairy cattle. Journal Dairy Science, 91:418-426.

Stoltenow, C. L. and L. L. Vincent, 2003. Calf scours causes, prevention, and treatment. NDSU Extension service North Dakora State University. http://www.ag.ndsu.edu/pubs/ansci/beef/as776 .pdf.

Tozer, P.R. and A.J. Heinrichs, 2001. What affects the costs of raising replacement dairy heifers: A multiple- component analysis. Journal Dairy Science, 84:1836-1844.

USDA, 2007. Part 1: Reference of Dairy Cattle Health and Management Practices in the United States, 2007. NAHMS Dairy 2007:1128.

Van Amburgh, M.E., D.M. Galton, D. E. Bauman, R. W. Everett, D. G. Fox, L. E. Chase and H. N. Erb, 1998. Effects of three prepubertal body growth rates on performance of Holstein heifers during first lactation.Journal Dairy Science, 81:527-538.

Vergara, O.D., M.A. Elzo and M.F Ceron Munoz, 2009. Genetic parameters and genetic trends for age at first calving and calving interval in an Angus-Blanco Orejinegro-Zebu multibreed cattle population in Colombia. Livestock Science, 126:318-322. 
Villarroel, A, T.B. Miller, E.D. Johnson, K.R.

Noyes and J.K .Ward, 2013. Factors Affecting Serum Total Protein and Immunoglobulin G Concentration in Replacement Dairy Calves. Advanced Dairy Research, 1:106 - 111.

Wasike, C.B., D. Indetie, J.M.K. Ojango and A.K.

Kahi, 2009. Direct and maternal (co)variance components and genetic parameters for growth and reproductive traits in the Boran cattle in Kenya. Tropical Animal Health Production, 41:741-748.

\section{المكافى الوراثى والارتباطات الوراثية للعمر عند أول ولادة كتأثير بموائمة العجول الرضيعة والحالة الصحية

محمد سليمان موسى1، أنتونى جيمس سيكورا2، محمد أبو القاسم عبد اللطيفّ وعماد فهمى موسى؛؛,

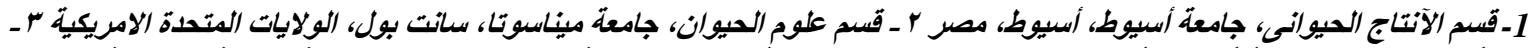

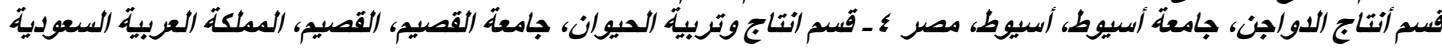

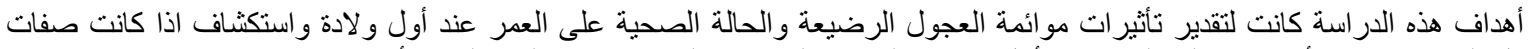

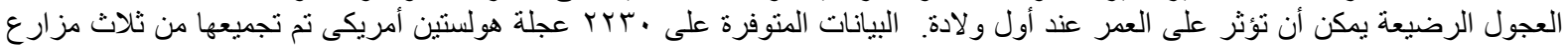

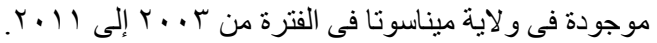

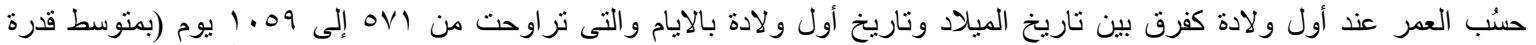

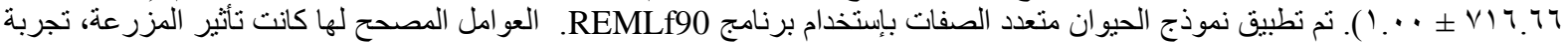

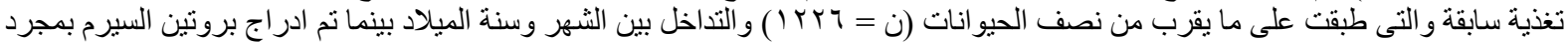

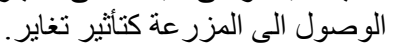

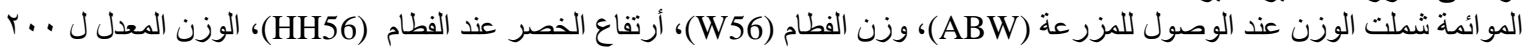

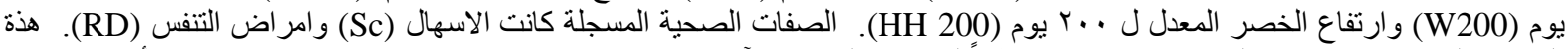

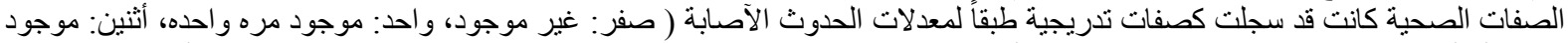

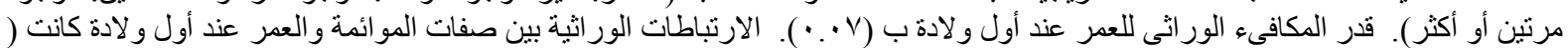

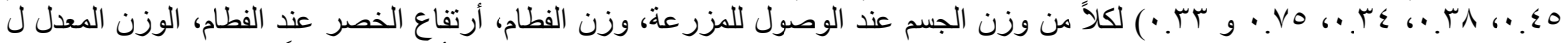

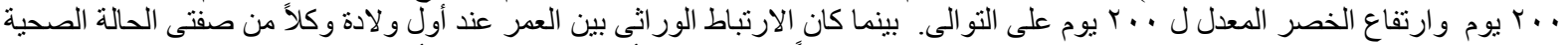

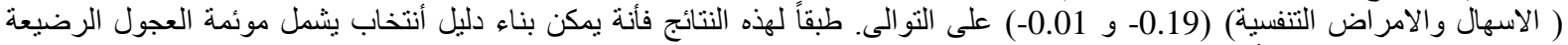
والاداء الصحى والعمر عند أول ولادة. 